\title{
Private InTERests, Public Borders, AND THE NAFTA'S CHAPTER 11: LESSONS FROM THE MAD-COW SAGA
}

\author{
RyAN ClementS AND MOIN A. YAHYA*
}

This article provides a detailed overview of the mad-cow saga that took place from 2003 until 2005, and discusses its adverse impact on the economic markets of Canada and the United States in terms of trade synergies and amicable commercial relationships. The authors go on to discuss the remedies and dispute resolution mechanisms offered by the NAFTA, particularly c. 11. Ultimately, the article argues that c. 11 is a useful tool for parties to redress their loss when they have been subjected to unfair treatment by interest groups that pursue litigation in domestic courts. This argument is grounded in a discussion of Leowen v. O'Keefe and the litigation pursued by Ranchers Cattlemen Action Legal Fund.
Cet article donne un aperçu détaillé de la saga de la vache folle que l'on a connue de 2003 à 2005 et examine son effet nuisible sur les marchés économiques canadiens et américains en termes de synergies commerciales et relations commerciales amicales. Les auteurs discutent ensuite des remèdes et des mécanismes de résolution de conflits possibles en vertu de l'ALÉNA, tout spécialement l'article 11 de l'Accord. Malheureusement, l'article fait valoir que cet article 11 est un outil utile pour les parties qui désirent récupérer leur perte après avoir été injustement traitées par des groupes d'intérêt intentant des poursuites dans les tribunaux nationaux. Cet argument est fondé dans une discussion de Leowen c. O’Keefe et les poursuites intentées par Ranchers Cattlemen Action Legal Fund.

\section{TABLE OF CONTENTS}

I. INTRODUCTION . . . . . . . . . . . . . . . . . . . . . . . . . . 382

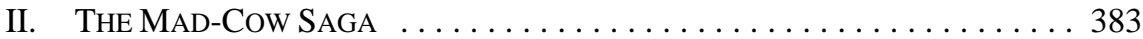
A. THE CANADIAN BSE CRISIS AND

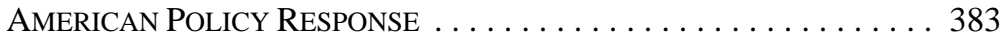
B. AMERICAN PRIVATE INTEREST
C. R-CALF LEGAL MANOEUVRES AND

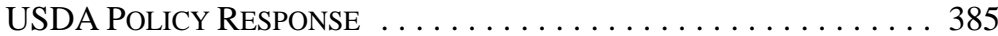

III. POTENTIAL ECONOMIC RELIEF:

NAFTA CHAPTER 11 ARBITRATION . . . . . . . . . . . . 389

IV. CHAPTER 11 AND MAD-COW $\ldots \ldots \ldots \ldots \ldots \ldots \ldots \ldots \ldots \ldots . \ldots \ldots$

A. CuRrent BSE Chapter 11 Claims AND

AMERICAN INTERPRETIVE REPLY . . . . . . . . . . . . . 393

B. CHAPTER 11 ARBITRATION AND THE

BSE CRISIS: OPPORTUNITIES AND CHALLENGES . . . . . . . . . . . 394

C. APPLICABILITY OF THE NAFTA REMEDIAL PROVISIONS

TO PRE-EMPTIVE PRIVATE INTEREST ACTIONS . . . . . . . . . 396

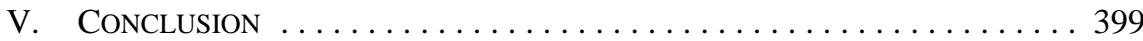

Mr. Clements is currently an articling student at the Toronto office of Davies Ward Phillips \& Vineberg LLP. He obtained his LL.B. with distinction from the University of Alberta in 2007. Mr. Yahya is an Assistant Professor of Law at the University of Alberta. We would like to thank Russell A. Miller, Rebecca M. Bratspies, Linda C. Reif, Jeffery Atik, Frank J. Garcia, and participants at the Symposium. All errors are the authors'. 


\section{INTRODUCTION}

During 2003 to 2005, the mad-cow saga was a mainstay in Canadian media reports and provided ample fodder for both dinner table and high-level government foreign policy discussions. Its context played to some of the most fundamental human sentiments: fear of the unknown and the desire to preserve good health. Yet its impact, particularly on the United States and Canadian economic markets, has threatened trade synergies and amicable commercial relationships. The result was a resurgence of protectionist sentiments and a strengthening of the role of private interest lobbying groups in impacting, even dismantling, state-directed foreign policy decisions. The negotiators of the North American Free Trade Agreement Between the Government of Canada, the Government of Mexico and the Government of the United States ${ }^{1}$ foresaw such disputes and created a set of remedies and dispute resolution mechanisms that would allow aggrieved parties to seek redress from neutral (or at least less biased) panels. One such redress mechanism is c. 11 of NAFTA, which allows parties unfairly targeted because of their nationality to seek redress at a NAFTA panel. The closing of the border and the targeting of Canadian cattle by the Ranchers Cattlemen Action Legal Foundation (R-CALF), a private interest special group representing American cattle ranchers, in our opinion constituted an example of such unfair treatment.

This article argues that when special interest groups are able to use their domestic courts to target foreign exports, c. 11 should be a viable choice to seek redress and compensation for any loss sustained by the success of such judicial action. We base our analysis on the infamous case of Loewen v. O'Keefe, ${ }^{2}$ where a Canadian funeral home company was successfully sued in a state court for breach of contract. In Loewen, the plaintiffs portrayed a Canadian defendant as an outsider invading and mistreating Americans, especially the plaintiff, which in turn inflamed the jury's passions. The resulting verdict ultimately bankrupted the Canadian company, which appealed its predicament to a NAFTA c. 11 panel. The panel was sympathetic and willing to find a violation of the Canadian company's rights under NAFTA. We argue that such an analysis is equally applicable in the case of Canadian cattle producers.

Where the domestic judiciary becomes the tool of protectionism, c. 11 should be a viable tool for the foreign producers whose exports were blocked by a domestic special interest group's use of the judiciary. The article will proceed as follows: Part II will give an overview of the legal battles associated with the mad-cow saga, Part III will explain the basics of the NAFTA c. 11 arbitration process, Part IV will reflect on c. 11's applicability to claims arising from the mad-cow events, and Part V will offer concluding thoughts.

17 December 1992, Can. T.S. 1994 No. 2, 32 I.L.M. 289 (entered into force 1 January 1994) [NAFTA]. The Loewen Group, Inc. v. United States (2003), ICSID Case No. ARBCAF/98/3 (International Centre for Settlement of Investment Disputes), online: NAFTA Claims <http://naftaclaims.com/Disputes/USA/ Loewen/LoewenFinalAward.pdf $>$ [Loewen]. 


\section{The Mad-Cow SAga}

\section{A. The Canadian BSE Crisis ANd American Policy Response}

On 20 May 2003, reports first surfaced of a confirmed case of bovine spongiform encephalopathy (BSE) detected in a cow in the Peace River district of northern Alberta. ${ }^{3}$ BSE, otherwise known as "mad-cow disease," is a degenerative neurological disease that affects the central nervous system in cattle. Prior to this news, beef consumers in Canada and the U.S. were only vaguely familiar with the disorder as a result of its impact in the United Kingdom. BSE first surfaced in the U.K. in 1986, and from the period of 1986 to 2003, there were over 180,000 reported cases of the disease. ${ }^{4}$ Furthermore, by 1992 it could be said that BSE in the U.K. had reached the status of "epidemic," with over 1000 new cases being reported each week. ${ }^{5}$

At the time of Canada's first case of "mad-cow," it was well known in scientific circles that a variant of the disorder, known as Creutzfeldt-Jakob Disease (CJD) could be transmitted to humans through the consumption of contaminated meat. ${ }^{6}$ This knowledge undoubtedly played a role in the devastating impact that the BSE detection had on U.S. and Canadian domestic markets. ${ }^{7}$ The U.S. Department of Agriculture (USDA) reacted swiftly to the news, banning all imports of Canadian cattle and beef products. ${ }^{8}$ Japan and Australia closely followed suit, delivering a devastating blow to export-dependant Canadian cattle producers. ${ }^{9}$

The protective measures instituted by the U.S. quickly caused the CDN\$7 billion per year Canadian cattle and beef industry to declare itself in a state of crisis, and prompted prominent industry players such as the Chairman of the Canada Beef Export Federation to describe the situation as "[t]he biggest challenge I've ever seen." ${ }^{10}$ Such sentiments quickly reached Edmonton and Ottawa as then Premier Ralph Klein and then Prime Minister Jean Chrétien were summarily petitioned to aid the ploy of these embattled producers. ${ }^{11}$

Fortunately, nearly three months after the initial moratorium on imports, the USDA announced that it would partially lift its ban on Canadian beef. ${ }^{12}$ This welcome shot in the

Joseph T. Hallinan \& Mark Heinzl, "Case of Mad-Cow Disease in Canada Shakes Markets Across Continents” The Wall Street Journal (21 May 2003) B1.

Judith A. Johnson \& Donna V. Vogt, “'Mad Cow Disease’ or Bovine Spongiform Encephalopathy: Scientific and Regulatory Issues” in Geoffrey S. Becker, ed., Mad Cow Disease: Are We Safe? (New York: Novinka, 2004) 29 at 33.

Carol Steinhart, “Chemistry behind the News: Sick Cows, Protein Geometry, and Politics” (1996) 73 J. Chem. Educ. A232.

Garazi Andonegi, “Protein Involved in 'Mad Cow’ Disease” Medical News Today (19 October 2005). Hallinan \& Heinzl, supra note 3.

Jill Mahoney, "Mad-cow hits Canada hard: Alberta infection prompts U.S. ban on Canadian beef and raises fears for cattle industry” The Globe and Mail (21 May 2003) A1.

Ibid.

Charlie Gillis, "Mad-cow disease strikes Canada: First case in 10 years dooms Alberta herd: U.S. temporarily bans imports of Canadian livestock and beef products” National Post (21 May 2003) A1. See also Tony Seskus \& Paul Haavardsrud, “Alberta's agriculture industry on the brink: Mad cow 'like a double-whammy hitting us now”” National Post (22 May 2003) FP1.

Gillis, ibid.

Dave Ebner, "Another cow may have BSE; Conclusive results on the 10-year-old dairy animal may be available in about a week” The Globe and Mail (31 December 2004) A2. 
arm to Canadian domestic cattle producers became merely a fading hope as in August 2003, a second case of BSE was detected in a Washington State cow with Alberta roots, thereby prompting a re-closure of the border. ${ }^{13}$ This ban remained until 18 April 2004, when the USDA announced that it would allow the importing of all Canadian ground beef and bone-incut beef from animals younger than 30 months (animals too young to contract BSE). ${ }^{14}$

For the most part, the August 2003 re-closure prevented American consumers from obtaining any cuts of Canadian beef. The Wall Street Journal revealed, however, that in October of 2003, the USDA had implemented an undisclosed policy modification making it possible for U.S. importers to buy about 5.6 million pounds of boneless boxed beef and trimmings from cattle under 30 months old. ${ }^{15}$

The trade restriction imposed until the 18 April 2004 announcement cost the Canadian beef industry nearly CDN\$2 billion, and threatened to destroy many family owned farms and ranches. ${ }^{16}$ It was estimated that the April 18 opening of the border would inject over $\$ 170$ million a year into the Canadian beef market, money that was desperately needed. ${ }^{17}$ There was finally hope for the devastated industry that longed for the trade restrictions to be fully lifted. This hope turned out to be premature, however, as a fierce legal battle between an American private interest group and the USDA was about to begin. ${ }^{18}$ This legal battle lasted a year, and undoubtedly exacerbated the losses suffered by Canadian cattle producers.

\section{B. American Private Interest Pressure: R-CALF}

While Canadian beef and cattle producers were engaging the sympathies of their respective representative governments, another private interest group took a significant interest in the developing saga and organized what would eventually become a long and litigious crusade against U.S. beef imports from Canada. The Ranchers-Cattlemen Action Legal Fund, United Stockgrowers of America, otherwise known as R-CALF, is an organization of ranchers that was founded in $1999 .{ }^{19}$ Originating from grassroots efforts, RCALF has become a veritable force in the U.S. agricultural industry, increasing its membership to over 18,000 in $2005 .^{20}$ Largely protectionist in its mandate, R-CALF was instituted to zealously advocate the interests of American domestic beef producers in the increasingly competitive global beef trade. ${ }^{21}$

Ibid.

Barrie McKenna, "Canada fears fallout over U.S. beef gaffe; Banned produces let in; congressmen demand labeling” The Globe and Mail (21 May 2004) B4.

Bill Tomson, “U.S. Helped Canada Beef Imports Despite 'Mad-Cow' Concerns” The Wall Street Journal (1 June 2005) C5.

Jason Markusoff, “Expert panel tells U.S. to lift trade barriers on cattle: More mad cow cases south of border likely, report says” National Post (5 February 2004) A5.

"Fair Trade in Beef,” Editorial, National Post (20 April 2004) A15.

Kate MacNamara, "Mad cow's toll keeps mounting: The continuing refusal by the United States to accept Canadian live beef has swollen herds and depressed prices” National Post (25 October 2004) FP1.

9 Jim Robbins, “Cattlemen’s Group Wrangles With Its Former Allies” The New York Times (14 September 2005) A16, online: The New York Times <http://www.nytimes.com>.

Ibid.

Tamsin Carlisle, “Canada’s Ranchers Battle Glut; With U.S. Border Still Closed to Cattle, Lean Times Are Being Felt” The Wall Street Journal (28 July 2004) B3. 
Like the USDA, R-CALF was also quick to react to the BSE crisis north of its border. Initially its efforts were primarily non-litigious in nature as it utilized its lobbying power to catch the attention of Washington. R-CALF first lobbied for a long, extended beef ban and the imposition of a seven-year Canadian BSE-free history before the border would be open to any cuts of Canadian beef. ${ }^{22}$ When the USDA continued to make incremental reductions from its initial total ban on Canadian beef, R-CALF adopted more aggressive methods and sought to utilize the courts as a mechanism to prevent the USDA from engaging in measures it felt would impact its economic affairs, as the following discussion will demonstrate.

\section{R-CALF LEgAL MANOEUVRES AND USDA POLICY RESPONSE}

Prior to the BSE crisis, R-CALF had engaged in the litigation process, especially against the federal government. For example, in 1999, they unsuccessfully fought a negative preliminary injury determination by the International Trade Commission in the U.S. Court of International Trade concerning live cattle imported from Mexico. ${ }^{23}$ Other than this case, however, R-CALF had not engaged in any major litigation to speak of; certainly not on the scale that brought a nation's cattle industry to its knees.

Shortly after the 18 April 2004 import relaxation, R-CALF successfully obtained a temporary restraining order against the USDA in the Federal District Court of Montana. ${ }^{24}$ In issuing his decision, Cebull J. of the U.S. District Court held that R-CALF had standing to bring such an action under the Administrative Procedure Act. ${ }^{25}$ He held that the USDA's rule relaxing the import restrictions was arbitrary and capricious, and that the Department was ignoring its statutory mandate to protect the health and welfare of the people of the U.S. Furthermore, despite USDA econometric and scientific data to the contrary, he posited that the USDA had erroneously calculated the prevalence of BSE in Canada, and that the introduction of BSE into the U.S. would cause irreparable harm to the American public because of the increased risk of CJD to beef consumers.

This temporary restraining order was converted into a preliminary injunction on 5 May 2004, prompting USDA Inspector General Phyllis Fong to accede to a request by Democratic Senators to investigate the April 18 import decision. ${ }^{26}$ Undeterred, however, from its initial judicial setback, the USDA announced on 29 December 2004 the issuance of a final rule declaring Canada as a region of "minimal” BSE risk, thereby lifting the Canadian beef trade ban. ${ }^{27}$ R-CALF vowed to fight this proposed action. It was particularly incensed when, on

Dawn Walton, "U.S. group wants beef ban extended Ranchers suggest seven-year window for Canada to prove disease is contained" The Globe and Mail (3 June 2003) A10. Ranchers-Cattlemen Action Legal Foundation v. United States, 74 F.Supp.2d 1353 (Ct. Int. Trade 1999). Ranchers-Cattlemen Action Legal Fund United Stockgrowers of America v. United States Department of Agriculture, 2004 WL 1047837 (Mont. Dist. Ct.).

5 U.S.C. $\S 500$ (1946) [APA].

Carlisle, supra note 21. See also John Ivison, “Cattlemen suffer as border still closed” National Post (15 October 2004) A6.

Carlisle, ibid. 
5 January 2005, another Alberta domestic cow had been positively identified as having $\mathrm{BSE}^{28}$

R-CALF successfully responded to the proposed policy action by obtaining a preliminary injunction on 2 March 2005, again from Cebull J., in the Federal District Court. ${ }^{29}$ Judge Cebull's decision largely echoed his sentiments a year earlier, stressing the likelihood of RCALF's ability to prevail against the USDA under the APA. Again, he noted that the USDA had inadequately addressed the mad-cow concern when it failed to conduct a quantitative assessment of the risk imposed on human health, given the discovery of additional cases of domestic Canadian BSE, and the lack of mandatory testing standards for Canadian beef imported into the U.S. Judge Cebull also chastised the USDA for failing to prepare an environmental impact statement (EIS), pursuant to their obligations under the National Environmental Policy Act, ${ }^{30}$ and also stated that the USDA violated the Regulatory Flexibility $\mathrm{Act}^{31}$ by not carefully considering the impact of importation allowance on small ranchers, and by not evaluating alternatives that might protect ranchers, such as requiring country of origin labeling on meat and inspection.

The USDA appealed the injunction to the U.S. Court of Appeals for the Ninth Circuit. ${ }^{32}$ On 25 July 2005, Tashima J. for the Ninth Circuit reversed Cebull J.'s temporary injunction. In doing so, he offered strong words in support of the principle of legislative deference. Citing National Association of Home Builders v. Norton, ${ }^{33}$ the Court stressed the principle that regulations are presumed to be valid and stated that it was an error to accept the scientific judgments of R-CALF over the expert findings of the USDA. ${ }^{34}$ Furthermore, under the Animal Health Protection Act ${ }^{35}$ the USDA was not required to remove all risk of BSE entering the U.S; it was Congress's intent to give the Secretary of Agriculture wide discretion in dealing with the importation of plant and animal products. ${ }^{36}$

The Court also noted that substantial evidence supported the USDA's conclusion that easing the total ban on Canadian ruminant imports would not significantly increase the risk of the American population to BSE. ${ }^{37}$ There was a low incidence of BSE in Canadian cattle, and Canada's existing feed ban, coupled with its import restrictions on cattle from high BSE

Bill Tomson, “Group Plans Fight to Keep Ban On Canadian Cattle in Place” The Wall Street Journal (29 November 2004) C2. See also Tasmin Carlisle, "US Plans To Lift Canada Cattle Ban; Resumptions of Imports Would End Trade Dispute, May Ease High Beef Prices” The Wall Street Journal (30 December 2004) B3; Clifford Krauss, "Canada Suspects 2nd Case of Mad Cow Disease” The New York Times (31 December 2004) A7, online: The New York Times <http://www.nytimes.com>.

Ranchers-Cattlemen Action Legal Fund United Stockgrowers of America v. United States Department of Agriculture, Animal And Plant Health Inspection Service, 359 F.Supp.2d 1058 (2005). See also Scott Kilman, "Judge Tells USDA to Keep Barring Canadian Cattle” The Wall Street Journal (3 March 2005) B2; “The Rockies: Montana: A No to Canadian Beef,” National Briefing, The New York Times (3 March 2005) A25, online: The New York Times <http://www.nytimes.com>. 42 U.S.C. § 4321 (2000) [NEPA].

5 U.S.C. § 601 (1980) [RFA].

Ranchers-Cattlemen Action Legal Fund United Stockgrowers of America v. United States Department of Agriculture, 415 F.3d 1078 (9th Cir. 2005) [R-CALF].

340 F.3d 835 (9th Cir. 2003).

$R$-CALF, supra note 32 at 1093.

7 U.S.C. § $8301 \mathrm{ff}(2002)$.

$R-C A L F$, supra note 32 at 1094-96.

Ibid. 
risk regions, ensured that the Canada's BSE prevalence rate would not rise dramatically. Canada had also taken other measures, such as BSE testing and epidemiological investigations, to identify and understand the source of BSE in its cattle population. Additionally, under the proposed policy of allowing select types of Canadian beef into the U.S., the USDA would only permit the importation of a subset of cattle that are extremely unlikely to have BSE - those under 30 months of age. ${ }^{38}$

The Ninth Circuit noted that Cebull J. paid no consideration to the 1998 USDA commissioned "Harvard-Tuskegee Study," which evaluated the likely effects of the introduction of BSE into the U.S. This study formulated that if the U.S. were to import 10 infected cows from Canada, there would likely be only 3 new cases of domestic BSE. ${ }^{39}$ In any event, the study concluded that "the disease was virtually certain to be eradicated from the United States within 20 years. ${ }^{40}$

The Court also found that R-CALF was unlikely to succeed in an RFA claim and that its allegations against the USDA fell outside of NEPA's zone of interests for the purpose of standing, since NEPA was instituted to protect the environment, and the bulk of R-CALF's allegations were related to the economic interests of the group's members. ${ }^{41}$ In the event that R-CALF was able to satisfy the NEPA "zone of interests” test, its claim would have inevitably failed because it lacked organizational standing to assert a NEPA challenge. ${ }^{42}$

As an aside, it is noted that R-CALF was not the only lobby interested in the preliminary injunction appeal. Both the National Meat Association (NMA), an American-based meat processing and slaughtering pressure group, and the Canadian Cattlemen's Association and Alberta Beef Producers (CCA/ABP) sought leave, as of right, to appeal Cebull J.'s decision. In a decision issued concurrently with the above noted appeal, however, the Ninth Circuit denied the intervention requests. ${ }^{43}$

Reports of the successful appeal flooded the major news wires and provided welcome relief to the many battle-weary ranchers and cattle producers eager to resume their business operations. ${ }^{44}$ At the time of the decision, the Canadian cattle industry had lost an estimated CDN\$7 billion because of the live cattle ban. ${ }^{45}$

R-CALF attempted to seek summary judgment on a motion for a permanent injunction (as opposed to the preliminary injunction that was the subject of all the prior litigation) on 27

Ibid. at 1099 .

Ibid. at 1097.

Ibid.

Ibid. at 1101-104.

Ibid.

Ranchers-Cattlemen Action Legal Fund United Stockgrowers of America v. United States Department of Agriculture, 143 Fed. Appx. 751 (9th Cir. 2005).

See “Slapping down Judge Cebull: Informed sources,” Editorial, National Post (27 July 2005) A14; “It's official: Our beef is safe,” Editorial, National Post (27 July 2005) A14.

Simon Doyle, “U.S. Opens way for Canadian cattle: 'Wonderful news': Exports could resume next week” National Post (15 July 2005) A4. 
July $2005 .^{46}$ This hearing was delayed so that Cebull J. could effectively study the Ninth Circuit's decision. ${ }^{47}$ On 13 October 2005, R-CALF petitioned the Ninth Circuit for a rehearing en banc. They were summarily denied. ${ }^{48}$

Finally, on 5 April 2006, Cebull J., the judge responsible for issuing the March 2005 preliminary injunction, denied R-CALF's application for summary judgment. ${ }^{49}$ Despite his earlier apparent protectionist sentiments, Cebull J. denied R-CALF's request and declared all pending motions on behalf of the organization moot, thereby ending the year-long chapter in the private interest group's legal battle against Canadian beef.

To this day, however, R-CALF has not given up on its fight to secure the American border from Canadian beef. Its latest legal tactic involves a 26 December 2006 brief submitted to the Ninth Circuit. ${ }^{50}$ In this appellate brief, R-CALF argues that Cebull J. was in error when he based his denial of its application for summary judgment solely on the Ninth Circuit Court of Appeals' decision vacating the preliminary injunction, without considering the merits of those motions and the supporting affidavits. ${ }^{51}$ Meanwhile, the USDA indicated that its plans to lift most of the remaining import restrictions on beef and cattle from Canada. In a statement issued on 5 January 2007, the USDA suggested that it hoped to allow Canadian imports for all ages of cattle, including those born before 1 March 1999 as the animals only pose a "minimal risk" for BSE..$^{52}$

Although ultimately unsuccessful, R-CALF's legal battle against the USDA demonstrated the potential devastating impact that one American private interest group can have on Canadian commercial ventures. Before obtaining its 2 March 2005 temporary injunction, some dismissed the group as a "vociferous little lobby group with protectionist leanings, but without much sway." 53 Its ability to obtain the temporary injunction, however, demonstrated that even a small private interest groups, combined with the right mix of judicial activism, could be capable of delivering economic death blows.

Due to the export-driven nature of the Canadian beef market, the Canadian cattle industry was severely affected. Media reports generally estimated the economic losses in the range of CDN\$7 billion. ${ }^{54}$ These losses were marginally sustained on the backs of Canadian

exei Barriounuevo, “Beef Imports From Canada To Resume” The New York Times (16 July 2005) 2; Alexei Barriounuevo, "Despite Concerns on Mad Cow, Court Allow Canada Imports" The New York Times (15 July 2005) A12, online: The New York Times <http://www.nytimes.com>. Dawn Walton, "U.S. judge cancels hearing on border closings; Case to determine if Canadian cattle should be shut out permanently may be unnecessary” The Globe and Mail (21 July 2005) A7. ohn Cotter, "U.S. cattle producers trying to reclose border to beef” The Globe and Mail (10 Septembe 2005) A15; John Cotter, "Mad-cow disease still costs farmers millions; U.S. border closed to normal trade" The Globe and Mail (11 October 2005) A8.

49 "U.S. Group loses bid to block Canadian beef" The Globe and Mail (6 April 2006) A9.

$50 \quad$ Ranchers-Cattlemen Action Legal Fund United Stockgrowers of America v. United States Department of Agriculture, 499 F.3d 1108 (9th Cir. 2007).

Ibid.

"U.S. plans to ease limits on Canadian cattle” The Globe and Mail (5 January 2007) B8.

Dawn Walton, "Litigious beef lobby group scores a big win; Lawsuits have made R-CALF few friends" The Globe and Mail (3 March 2005) A9.

$54 \quad$ Katherine Harding, “'Big development’ over beef; Canada’s ranchers hopeful after U.S. announcement about mad-cow case” The Globe and Mail (27 June 2005) A4. 
taxpayers, as the federal government and Alberta provincial government contributed CDN\$50 and \$30 million, respectively, in emergency trade subsidies to develop new markets. ${ }^{55}$ The federal government was particularly attuned to the circumstances of the beef industry; by 2005 it had allocated nearly CDN\$2 billion in funding programs related to madcow relief. ${ }^{56}$

The Canadian cattle and beef industry was not the only economic interest that suffered as a result of R-CALF's persistent and effective litigation strategy. The U.S. meat-packing industry, which lobbied heavily to get the border re-opened, was also substantially affected by the trade restrictions, and lost an estimated 8000 jobs because of the trade restrictions. ${ }^{57}$ For the most part, the meat packers were not nearly as successful as R-CALF in protecting their interests. The industry, as noted earlier, was unsuccessful in obtaining standing as an intervener in R-CALF’s litigation. ${ }^{58}$

What became invariably clear from the BSE crisis, given R-CALF's effective utilization of the U.S. court system, is that a private interest group's actions can result in devastating international economic consequences. The next section will examine whether existing trade agreements provide alternate recourse for those Canadian industry players affected by RCALF's judicial success. Particularly, the arbitration mechanisms related to foreign investment in NAFTA's c. 11 will be examined, and both the likelihood and the consequences of a successful BSE-driven claim will be discussed.

\section{POTENTIAL ECONOMIC RELIEF: NAFTA CHAPTER 11 ARBITRATION}

A potential remedy for Canadian companies affected by pre-emptive legal action instigated by American private interest groups is to claim a violation of c. 11 of the NAFTA. ${ }^{59}$ This chapter is based, to a large extent, on the investment provisions in the Free Trade Agreement between the Government of Canada and the Government of the United States of America. ${ }^{60}$

Chapter 11 of the NAFTA section entitled "Investment” deals with establishing minimum standards for equal treatment of investors of all parties to the agreement. ${ }^{61}$ Article $1102(1)$, for example, mandates that each Party to the agreement "shall accord to investors of another Party treatment no less favorable than that it accords, in like circumstances, to its own

$55 \quad$ Judy Monchuk, "Beef trade bolstered by \$50 million; Federal money to develop new markets for industry hit by drawn-out BSE crisis” The Globe and Mail (11 March 2005) A7. Dawn Walton \& Barrie McKenna, "U.S. Senate backs border ban on Canadian beef; Vote shows Bush and Congress at odds, increases changes of a long legal fight” The Globe and Mail (4 March 2005) A4. Dave Ebner, "U.S. ruling raises hope for end to cattle ban” The Globe and Mail (15 July 2005) A1.

\section{Supra note 43.}

Supra note 1.

2 January 1988, Can. T.S. 1989 No. 3, 27 I.L.M. 293 (entered into force 1 January 1989) [CUSFTA]. See also Richard Levin \& Susan Marin, "NAFTA Chapter 11: Investment and Investment Disputes, 2Sum NAFTA” (1996) L \& Bus. Rev. Am. 82; Jack J. Coe, Jr., "Taking Stock of NAFTA Chapter 11 in Its Tenth Year: An Interim Sketch of Selected Themes, Issues, and Methods” (2003) 36 Vand. J. Transnat'l L. 1381. 
investors with respect to the establishment, acquisition, expansion, management, conduct, operation, and sale or other disposition of investments."62 Under NAFTA c. 11 a private corporation, based in one signatory state, can sue a signatory directly rather than applying to its domestic government to proceed with a nation-to-nation complaint under c. 20 of the treaty. ${ }^{63}$ The matter is heard before an arbitration panel if it is alleged that one or more of arts. $1102-1111$ of the NAFTA treaty has been breached. Since proceedings are brought against a signatory directly, a successful arbitration will result in the sovereign signatory being financially liable for economic losses incurred by the company, or private interest, affected by the NAFTA breach.

Since the enactment of this treaty, a number of claims have been brought against NAFTA signatories Canada, the U.S., and Mexico. To date, no Canadian company has ever been successful in a c. 11 arbitration claim against the U.S. As the following discussion establishes, there have been four arbitrations of this nature since the enactment of the provision.

In 1999, Mondev International Ltd (Mondev), a Canadian real-estate development corporation, which owned and controled a Massachusetts limited partnership, Lafayette Place Associates, claimed that a decision by the Supreme Judicial Court of Massachusetts breached the U.S.'s obligations pursuant to c. $11 .^{64}$ The dispute arose due to a breach of contract claim by a Canadian corporation against the City of Boston and the Boston Redevelopment authority. Despite a favorable jury verdict, the Supreme Judicial Council of Massachusetts (Massachusetts's highest court) overturned the verdict on grounds of statutory immunity and the lack of breach as a matter of law. Mondev claimed that the statutory immunity and finding of lack of breach as a matter of law violated the minimum standards requirements of art. 1105(1) of NAFTA. An arbitration panel dismissed this claim on 11 October 2002.

In 1999, Methanex Corporation, a Canadian marketer and distributor of methanol, submitted a claim alleging that the U.S. had breached its c. 11 treaty obligations because of California's enactment of a ban on the use or sale of the gasoline additive $\mathrm{MTBE}^{65}$ (in which methanol is a manufacturing ingredient). This claim was dismissed on 9 August 2005. ${ }^{66}$

Another unsuccessful claim was finalized in January 2003, in which ADF Group Inc., a Canadian corporation that designed, engineered, fabricated, and erected structural steel,

\footnotetext{
$62 \quad$ Ibid., art. 1102(1).

63 Ibid., c. 11, arts. 1116-17.

$64 \quad$ Mondev International Ltd v. United States, ICSID Case No. ARB(AF)/99/2 (International Centre for Settlement of Investment Disputes), online: U.S. Department of State <http:/www.state.gov/documents/ organization/14442.pdf> [Mondev]. See also Chad D. Hansen, “Mondev. International Ltd. v. United States: A Case Study of the Potential Risks of NAFTA’s Ever-Expanding Arbitration Provisions” (2003) 29 N.C. J. Int'l L. \& Com. Reg. 351.

65 Methyl tertiary-butyl ether.

66 Methanex Corporation v. United States (2005), online: NAFTA Claims <http://naftaclaims. com/Disputes/USA/Methanex/Methanex_Final_Award.pdf>.
} 
alleged that the federal Surface Transportation Assistance Act ${ }^{67}$ violated c. 11 by requiring that federally-funded state highway projects use only domestically produced steel. ${ }^{68}$

The most interesting case is the Loewen decision. ${ }^{69}$ What started out as a \$3.5 million contractual dispute between the Canadian Loewen Group, a funeral home conglomerate, and O’Keefe, a Mississippi-based funeral home operator, resulted in a US\$500 million jury award, \$400 million of which was comprised of punitive damages, and ultimately the financial ruin of the Canadian company. The trial featured theatrics worthy of a major motion picture. ${ }^{70}$ O’Keefe's flamboyant and populist lawyer, Willie E. Gary, effectively spun a routine and technical contractual allegation into a trial where the jurors believed that race, class, and U.S. nationalism were the key issues. During the trial, Gary made numerous references to the defendant's nationality and implied that he was defending his American client from a foreign attack. Unimpeded by the trial judge, Gary effectively portrayed the Loewen Group as a "greedy foreign invader out to deceive and cheat grieving consumers of funeral homes services."71 During the trial, allusions to Loewen's nationality were made over 50 times, with the trial judge always overruling Loewen's objections. ${ }^{72}$ During the trial, Gary published a full page color advertisement with the Mississippi and American flag opposite a Japanese and Canadian flag, with the captions "YES O’Keefe” under the American flag and "NO Loewen" under the Canadian flag. ${ }^{73}$ Gary inflamed the racial passions of the mostly black jury by focusing on how the plaintiff was not a racist, and by claiming that the Canadian firm was profiting by gouging black customers. ${ }^{74}$

The jury accepted this propaganda, and the result was an egregious civil damages award. Even though the damages returned did not conform with the laws of Mississippi concerning computation of damages, the trial judge did not correct it. To add insult to injury, Loewen's ability to appeal the decision was significantly impaired by a Mississippi state law requiring defendants to post a supersedeas bond equal to 125 percent of the total award. ${ }^{75}$ Rather than post the bond, and risk a similar miscarriage of justice on appeal, the Loewen group settled the suit out of court for $\$ 175$ million. This settlement, though, proved quite costly, and ultimately the company filed for bankruptcy. ${ }^{76}$

Seeking one last recourse, the Loewen Group and its proprietor Raymond L. Loewen sought recourse against the U.S. States via a c. 11 NAFTA arbitration. In support of their claim, they alleged that the Mississippi Court proceedings violated three provisions of c. 11

49 U.S.C. § 31105 (1982).

ADF Group v. United States (2003), ICSID Case No. ARBCAF/00/1 (International Centre for Settlement of Investment Disputes), online: U.S. Department of State <http://www.state.gov/ documents/organization/16586.pdf >.

Loewen, supra note 2. For a detailed overview of the Loewen case, see Michael I. Krauss, "NAFTA Meets The American Torts Process: O’Keefe v. Loewen” (2000) 9 Geo. Mason L. Rev. 69.

Those familiar with the South Park movie and its "Blame Canada" song would find the trial eerily similar. Stefan Matiation, "Arbitration with two Twists: Lowewen v. United States and Free Trade Commission Intervention in NAFTA Chapter 11 Disputes” (2003) 24 U. Pa. J. Int'l Econ. L 451.

Krauss, supra note 69 at 69.

Ibid. at 77.

Ibid.

Ibid. at 78.

Ibid. at 84 .

Ibid. at 86 . 
governing the treatment of foreign investors. At the time, this was the first NAFTA c. 11 claim made by a foreign corporation against another country's judiciary. ${ }^{77}$ Loewen claimed that the trial judge violated art. 1102 of the NAFTA, which deals with national treatment, by admitting the prejudicial anti-Canadian and pro-American evidence. ${ }^{78}$ Loewen also claimed that the large verdict and the miscalculation of the damages violated art. 1105, which concerns fair treatment of foreign parties, and art. 1110 of the NAFTA which deals with prohibition against expropriation. ${ }^{79}$

Despite the uniqueness of the trial circumstances and the severe nature of the appeal bond, a NAFTA arbitration tribunal dismissed the Loewen Group's claim on 26 June $2003 .{ }^{80}$ This was due to a technical detail, namely that the ownership of the Loewen group was now primarily an American company (due to the bankruptcy and reorganization proceedings whereby an American company acquired a majority share in Loewen), and hence, it could no longer claim discrimination based on country of origin. But for this glitch, however, the panel seemed to indicate that there was a very good case for awarding relief for Loewen.

Although the panel noted that Loewen did not exhaust all its domestic remedies, it noted that

By any standard of measurement, the trial involving O’Keefe and Loewen was a disgrace. By any standard of review, the tactics of O’Keefe's lawyers, particularly Mr Gary, were impermissible. By any standard of evaluation, the trial judge failed to afford Loewen the process that was due.

The methods employed by the jury and countenanced by the judge were the antithesis of due process. But we repeat this is only one instance of many. ${ }^{81}$

Although there has not been a successful challenge to a judicial action under c. 11, the Loewen case serves as a model for when such challenges could be sustained. A c. 11 challenge is sustainable if the NAFTA c. 11 claimant can show an egregious bias on the domestic judiciary's part against a foreign corporation where the outcome is simple protectionism. By protectionism, we mean that the domestic party prevailed against the foreign party simply because of both their nationalities. In the saga of R-CALF against Canadian beef, a similar situation emerged: a trade group whose concern was protecting domestic cattle producers sued in a friendly forum to prevent the entry of Canadian beef for over a year (and, if it had its way, forever). The issue will be revisited shortly.

Professor Krauss furthered such analysis by invoking the field of Public Choice. ${ }^{82}$ Public Choice is a field of study that examines public policy decision making from an economic

Ibid. at 70 .

Loewen, supra note 2 at para. 39.

Ibid.

Ibid.

Ibid. at paras. 119, 122.

Krauss, supra note 69 at 91-98. For an introduction to the field, see Gordon Tullock, Arthur Seldon \& Brady L. Gordon, Government Failure: A Primer in Public Choice (Washington, DC: Cato Institute, 2002) at 3-79. 
perspective. It has been used to study political decision making, ${ }^{83}$ as well as judicial decision making. ${ }^{84}$ For example, in the U.S., many state judges are elected. State judges are also elected by the local voters. This gives state judges an incentive to redistribute wealth away from out-of-state defendants to in-state plaintiffs. ${ }^{85}$ Since many of the lawyers representing the local plaintiffs are also local (and tend to contribute to the judges' election campaigns) and many of the out-of-state defendants' lawyers are also from out of state (and hence have not been able to contribute to the judges' campaigns), local judges may favour the local lawyers during trial. ${ }^{86}$ Given these factors, it is easy to see how a Canadian firm could suffer at the hands of the elected state judiciary. Chapter 11, on the other hand, creates an environment where it is harder for one side (or the other) to be favoured. ${ }^{87}$ The c. 11 arbitration panel is chosen on a bi-national basis, thereby making it impossible for the local state actors to capture the panel as they can capture the state judiciary. ${ }^{88}$ An impartial panel will most likely rule fairly, and award the grieving party a remedy that is monetary in nature. One problem, however, is that the cost of these arbitration awards is borne by the national taxpayer, thereby insulating the local actors from any direct consequences. ${ }^{89}$ Nonetheless, Krauss argues that c. 11 may still have some use in combating wealth re-distribution.

\section{CHAPTER 11 AND MAD-COW}

\section{A. CurRent BSE Chapter 11 Claims AND AMERICAN INTERPRETIVE REPLY}

In August 2004, a group called “Canadian Cattlemen for Fair Trade” (CCFT) ${ }^{90}$ announced that it was launching a suit against the U.S. under NAFTA c. $11 .{ }^{91}$ CCFT is a group of Canadian feedlot operators who claim to have been particularly affected by the U.S.'s policy response to Canadian BSE. Since this initial suit, there have been an additional 106 claimants who have submitted notices of arbitration under the arbitration rules of the UN Commission of International Trade Law (UNCITRAL), alleging that the U.S. violated c. 11 of the NAFTA

Krauss, ibid.

Ibid. at 91, n. 182, citing Eric Helland \& Alex Tabarrok, “Exporting Tort Rewards” (2000) 23 Regulation at 21.

Krauss, ibid. at 91-92.

This argument was raised in the case of Texaco, Inc. v. Pennzoil, Co., 729 S.W.2d 768 (Tex. Ct. App. 1987) at 833-34. The Court dismissed an allegation of bias against the trial judge who had received campaign donations from the plaintiff's lawyer and quoted approvingly from another case:

It is not surprising that attorneys are the principal source of contributions in a judicial election. We judicially know that voter apathy is a continuing problem, especially in judicial races and particularly in contests for a seat on an appellate bench. A candidate for the bench who relies solely on contributions from nonlawyers must reconcile himself to staging a campaign on something less than a shoestring. If a judge cannot sit on a case in which a contributing lawyer is involved as counsel, judges who have been elected would have to recuse themselves in perhaps a majority of the cases filed in their courts. Perhaps the next step would be to require a judge to recuse himself in any case in which one of the lawyers had refused to contribute or, worse still, had contributed to that judge's opponent.

Krauss, supra note 69 at 93-94.

Ibid.

Ibid.

See online: CCFT < http://www.ccft.info>.

"Beef producers file mad-cow claim against U.S.” The Globe and Mail (12 August 2004). 
by closing the border to the importation of Canadian cattle after an initial case of domestic Canadian BSE was found in an Alberta cow in 2003. ${ }^{92}$

The bulk of these claims focus on NAFTA art. 1102 and state that the U.S. has provided less favorable treatment to Canadian cattlemen than it has to U.S. cattlemen who own Canadian cows. ${ }^{93}$ In support of this allegation, the group claims that the U.S. failed to make any effort to roundup or trace Canadian cattle that had already crossed the border prior to its closing. ${ }^{94}$ It is also alleged that by "intentionally or negligently making and then failing to observe its commitments to eliminate its temporary ban on the importation of live cattle" the USDA breached the government's obligation to provide a minimum standard of treatment under international law and the NAFTA art. 1105(1). ${ }^{95}$ They further assert that this breach includes with it an obligation to pay restitution "for reasonable but detrimental reliance on government conduct or statements." 96

In response, the U.S. has largely dismissed the NAFTA based claims on the premise that the c. 11 remedial provisions do not apply to the current dispute. ${ }^{97}$ The U.S. asserts that it has neither the obligation to provide national treatment to Canadian-based investments, nor the obligation to arbitration claims relating to them. The U.S. interprets the NAFTA's c. 11 as being limited in scope to those investors that seek to make, are making, or have made, investments in the territory of the respondent state, and to those investments that those investors control. ${ }^{98}$ They submit that none of the NAFTA parties undertook any obligation with respect to investments located outside of its territory or with an "investor" who is not seeking to make, is not making, or has not made investments in its territory. ${ }^{99}$

If the BSE claimants are successful, the U.S. further asserts that every business that has been adversely affected by a border measure of another NAFTA party member would be an "investor" entitled to invoke a c. 11 dispute resolution. This would thereby provide a means for direct claims to be made by foreign nationals for matters that are quintessentially trade disputes, in clear circumvention of the provisions in c. 20 of the NAFTA, which provide for state-to-state dispute settlement procedures.

\section{B. CHAPTER 11 ARBITRATION AND THE BSE CRISIS: OPPORTUNITIES AND CHALLENGES}

The difficulty in predicting the outcome of these claims is that the matter is largely one of treaty interpretation and an attempt to delineate the purpose and intent of the arbitration mechanisms in c. 11. Concerning this point, the Canadian claimants position is strong

See "Cases Regarding the Border Closure due to BSE Concerns," online: U.S. Department of State $<$ http://www.state.gov/s/l/c14683.htm>.

Cor Van Raay v. United States, "Notice of Intent to Submit a Claim to Arbitration” (12 August 2004), online: U.S. Department of State <http://www.state.gov/s/l/c14683.htm> at 14.

Ibid.

Ibid.

Ibid. at 16.

Cor Van Raay v. United States, "Memorial on the Preliminary Issue of Respondent” (1 December 2006), online: U.S. Department of State <http://www.state.gov/s/l/c14683.htm>.

Ibid.

Ibid. 
because the language in the NAFTA contradicts the U.S.'s submissions regarding the importance of a temporal investment nexus. ${ }^{100}$ The definition section of the NAFTA investment provisions, art. 1139, defines an "investor of a Party" as "a Party or state enterprise thereof, or a national or an enterprise of such Party, that seeks to make, is making or has made an investment." ${ }^{\text {"101 }}$ Nowhere in NAFTA art. 1139 is it stated that the claimant must have made an investment in the territory of the other party. This could be a potentially costly omission, and a cause for concern on behalf of the U.S., as the BSE claimants do not actually state that they have actual business or property in the U.S., but rather argue that they have made investments in "the North American Free Trade Area" as required under art. 1139. ${ }^{102}$

One argument in favour of the U.S. position could be made, in light of previous c. 11 arbitration matters and international legal conventions, that the jurisdiction of an arbitration tribunal is based on the common consent of the parties to the dispute. ${ }^{103}$ Further, under principles of public international law, international tribunals have often insisted on an "unequivocal indication of a voluntary and indisputable acceptance" by a sovereign of a tribunal's jurisdiction. ${ }^{104}$

Again however, the matter of arbitration jurisdiction could largely be considered one of treaty interpretation. The U.S. position is that NAFTA, which delineates the scope of the American consent to arbitration, does not evidence consent to arbitrate BSE claims under c. 11. However, the Canadian claims are premised on their fulfilling the investment requirements under art. $1139 .{ }^{105}$ If this premise is true then, by virtue of art. $1122,{ }^{106}$ there is jurisdiction to arbitrate the matter, given that the U.S. has consented to the submission of all claims in accordance with the procedures set out in the NAFTA.

A major difficulty facing BSE claimants is that the USDA was arguably bound by federal administrative procedures in initially shutting down the border to Canadian beef. The basic claim of the Canadian cattlemen is that after the border was initially opened to cuts of boneless meat in August 2003, the USDA chose to observe a "time-consuming and unnecessary rulemaking process" instead of following scientific evidence that suggested that

McNall v. United States, “Notice of Intent to Submit a Claim to Arbitration” (30 May 2005), online: U.S. Department of State <http://www.state.gov/s/l/c14683.htm> at 39 [McNall].

NAFTA, supra note 1 at art. 1139.

McNall, supra note 100 at 40.

See Ethyl Corp v. Canada (1998), "Non-Institutional Award" (United Nations Commission on International Trade Law), online: Kluwer Law International <http://www.kluwerarbitration.com/ arbitration/Default.aspx> at para. 59: "The sole basis of jurisdiction under NAFTA c. 11 in an arbitration under the UNCITRAL Arbitration Rules is the consent of the Parties."

See Application of the Convention on the Prevention and Punishment of the Crime of Genocide (Bosnia and Herzegovina v. Ugoslavia (Serbia and Montenego)), Order of 13 September 1993, [1993] I.C.J. Rep. 325 at 342; see also Fireman's Fund Insurance Company v. Mexico (2003), "Decision on the Preliminary Question,” ICSID Case No. ARB(AF)/02/01 (International Centre for Settlement of Investment Disputes), online: ICSID Cases <http://www.worldbank.org/icsd/cases/pdf/FFIC_ Decision_on_Preliminary_Question_English.pdf> at para. 64: “[T]he Tribunal does not believe that under contemporary international law a foreign investor is entitled to the benefit of the doubt with respect to the existence and scope of an arbitration agreement.”

NAFTA, supra note 1, art. 1139.

Ibid., art. 1122. 
all forms of beef should be allowed in. ${ }^{107}$ In response, and in support of the U.S. position, however, U.S. law does not allow the USDA to follow its own evidentiary inclinations; ${ }^{108}$ rather, the USDA must follow its own regulations, which prohibit the importation of live cattle from regions in which BSE is known to exist. They also separately require that the public be given notice, and a chance to comment, before any nation is struck from the list of nations that are not allowed to import such products. ${ }^{109}$

\section{Applicability of the NAFta Remedial Provisions To Pre-EMptive Private INTEREst ACtions}

In contrast to the issues concerning the USDA closing the border to Canadian beef, the case against the actions by R-CALF seem stronger under c. 11. R-CALF's litigation strategy had a huge impact on the economic losses suffered by the Canadian cattle producers, and the question, therefore, is whether the loss attributable to R-CALF's actions, can, and should, be mitigated by the U.S. Government through NAFTA arbitration.

The factors in R-CALF's litigation against USDA and Canadian beef are as compelling as those in the Loewen litigation. The first is that the object of the litigation was Canadian beef, thereby making the object of the exclusionary judgment a product (beef) based on its national origin (Canada). Although the defendant in R-CALF's litigation was formally the USDA, the real target and object of the lawsuit was Canadian product. Though simply being targeted for being Canadian is not enough to win a c. 11 case, the fact that the trial judge seemed to favour R-CALF outright despite the established administrative law jurisprudence should weigh in the Canadian cattlemen's favour. Not only did the judge fail to give deference to USDA as required by the case law, he also took into account statutes that were irrelevant (such as NEPA) given that he had only granted standing to R-CALF.

Although the trial judge was not elected, nor even a state judge (he was an appointed federal judge), this does not preclude federal judges from having biases. Rather than the bias being in-state versus out-of-state, with state meaning one of the 50 American states, the bias may also translate into favouring America, the home nation, over Canada. Further, the fact that R-CALF chose the District Court of Montana for its litigation also appears to suggest a degree of forum-shopping, as it could have filed suit in almost any state in the Union. Forum shopping in the American Federal judiciary is quite common, especially in certain areas such as bankruptcy. ${ }^{110}$ In administrative law, parties can even forum shop for an appellate court when appealing a federal administrative agency's final determination, even

107 McNall, supra note 100 at 40.

108 Code of Federal Regulations, 9 C.F.R. $\S 94.18$ (a)(1) (2005).

$109 \quad$ Ibid., 9 C.F.R. § 92.2 (2005).

110 Bankruptcy is adjudicated in American federal courts, and there is considerable evidence that parties seek friendly judges to file their bankruptcy claims. See e.g. Todd J. Zywicki, "Is Forum Shopping Corrupting America’s Bankruptcy Courts?” (2006) 94 Geo. L.J. 1141; Theodore Eisenberg \& Lynn M. LoPucki, "Shopping For Judges: An Empirical Analysis of Venue Choice In Large Chapter 11 Reorganizations” (1999) 84 Cornell L. Rev. 967. There is also evidence of forum shopping in areas such as patent law: see e.g. Kimberly A. Moore, "Forum Shopping in Patent Cases: Does Geographic Choice Affect Innovation” (2001) 79 N.C.L. Rev. 889. 
though most federal agencies are located in Washington, D.C. ${ }^{111}$ The defendants, by contrast, (USDA and by implication the Canadian beef farmers) had no recourse against such shopping.

In terms of incentives to properly litigate the case, given that the real defendant was Canadian beef, the Canadian Ranchers Association would have had the maximal set of incentives to prepare and defend the case against R-CALF. Although the USDA adequately defended the lawsuits prevailing in the end on appeal, when the first injunction was obtained in 2004, the USDA took almost a year to prepare the required set of studies that conviced the Ninth Circuit to reverse the trial court's injunction. The fact that the USDA was willing to open the border in 2005 indicates that USDA had a good faith belief in the safety of Canadian beef. A good faith belief and the will to win at trial, however, are two different things. Had the Canadian Ranchers been permitted to intervene in the case from its inception, the border might have opened much earlier. The Canadian Ranchers would have been more aware of the nature of their beef, and not only would have prepared the appropriate studies in the fastest time possible; but they also would have had every incentive to do so.

There are further questions. It is not clear why R-CALF was granted standing, while the similarly affected National Meat Association (NMA) was denied it. R-CALF is a special interest group organized around protecting the economic interests of its members. Appropriately, the Ninth Circuit found that R-CALF did not have standing for asserting possible NEPA violations by the USDA.

Although R-CALF had standing to challenge opening the border, presumably because the tainted beef could have affected cattle owned by its members, it is not clear that R-CALF truly represented the public interest in the broad sense. ${ }^{112}$ For example, R-CALF's interests do not completely coincide with the interests of American beef consumers; if anything, its interests could be the opposite. Consumers, generally speaking, are interested in both price and quality of the products they consume. ${ }^{113}$ And so on the one hand, R-CALF's interest in seeing that the beef supply in the U.S. is safe serves one aspect of the public's interest. Less Canadian beef, however, means higher prices of beef and hence more profits for R-CALF's members. This is clearly good for R-CALF, but leaves the American beef consumers worse off. More Canadian beef imports would be better for the American consumer since it would lower the price, and this is precisely why the NMA would have wanted to intervene. RCALF's case was essentially one of protecting its domestic members against foreign competitors. At the very least, the judge should have allowed other associations, such as NMA and the Canadian Ranchers, to have intervener status.

111 Thomas O. McGarity, "Multi-Party Forum Shopping for Appellate Review of Administrative Action” (1980) 129 U. Pa. L. Rev. 302.

112 For an excellent introduction to the issues associated with public interest litigation and an associations' standing to bring such lawsuits, see Cindy Vreeland, "Public Interest Groups, Public Law Litigation, and Federal Rule 24(a)” (1990) 57 U. Chicago L. Rev. 279.

113 For a basic introduction to the idea that consumers look to price and quality, see e.g. Kelvin J. Lancaster, “A New Approach to Consumer Theory” (1966) 74 J. Pol. Econ. 132; Sherwin Rosen, "Hedonic Prices and Implicit Markets: Product Differentiation in Pure Competition” (1974) 82 J. Pol. Econ. 34. 
All in all, the treatment by the trial judge of the NMA, the Canadian Ranchers, and for that matter the USDA, suggest that the Canadian Ranchers were treated unfairly in violation of the U.S.'s obligations under NAFTA. The judiciary constitutionally functions as a separate and independent body from the legislative arm of the government. Judicial decisions are not typically characterized as government “policy” measures in a conventional sense. R-CALF's use of the courts, however, to drive its private policy agenda makes it clear that judicial action can have devastating economic consequences and arguably breach trade covenants.

One final factor that the Loewen case and the mad-cow saga share is the issue of exhaustion of domestic remedies. It is not clear that NAFTA requires the exhaustion of local remedies, ${ }^{114}$ nonetheless, as we saw earlier the NAFTA panel felt that Loewen had pursued as many domestic remedies as it could before being destroyed by the litigation. In the present case, the Canadian Ranchers were never allowed to litigate in the first place as formal defendants or as intervenors. All litigation was conducted against the USDA, and despite its prevailing in the end, the delay of over a year in opening the border was devastating to the Canadian ranching industry. On these two points, the issue of exhaustion of local remedies should be less of an issue than even in the Loewen case.

The relevant time period in this analysis is from 18 April 2004, when the USDA stated that it would relax all import restrictions, to 25 July 2005, when the Ninth Circuit struck down Cebull J.'s previously issued temporary injunction. The economic loss incurred by the Canadian cattle producers during this time frame is, arguably, solely attributable to RCALF's litigious measures in the Federal District Court, and not the USDA.

It should be noted that Loewen's c. 11 claims were based on art. $1105,{ }^{115}$ which deals with "Minimum Standard of Treatment," and art. 1110, ${ }^{116}$ which deals with "Expropriation and Compensation," and not the investment provisions in art. 1102. The difficulties that the Loewen Group faced in attaching a finding of liability against the U.S. are less applicable to the case of the BSE claimants. While art. 1105 of NAFTA makes the U.S. responsible for actions of its constituent units, ${ }^{117}$ and Loewen submitted that the term "constituent units" included the Mississippi State Judiciary, ${ }^{118}$ this issue does not apply here, as the BSE claimants' case would be against a U.S. Federal District Judge's actions. Since a federal court is clearly part of the U.S., the need to argue constituent units does not apply. The U.S. Supreme Court has held that state court judgments can be constituted as state government

Benjamin Klafter, "International Commercial Arbitration as Appellate Review: NAFTA's Chapter 11, Exhaustion of Local Remedies and Res Judicata” (2006) 12 U.C. Davis J. Int'l L. \& Pol'y 409 at 42829.

NAFTA, supra note 1 at art. 1105.

Ibid., art. 1110.

Ibid., art. 1105.

Krauss, supra note 69 at 90. 
action, ${ }^{119}$ and so a fortiori, the actions of a federal court should constitute state action for the purposes of NAFTA.

A finding of liability against the U.S. in the BSE c. 11 arbitration could have far- reaching positive consequences. From the R-CALF drama it is clear that private interest groups can wield a potentially dangerous economic sword. Further, the temporary injunction issued by Cebull J. show that the right combination of protectionism and judicial activism can legally thwart the imposition of legitimate, scientifically based health regulations, the consequences of which can be devastating to the foreign companies who depend on certainties to facilitate trade, and hedge risk.

\section{Conclusion}

Chapter 11 can serve as a useful tool when a special interest group is able to use the judiciary to further the interest of its members. When the foreign party is unable to be heard in the judicial chambers, thereby leaving its interests protected only by a domestic government agency, there is a case to be made that there was unfair treatment based on national origin. While no c. 11 litigation has been launched challenging specifically the RCALF saga (all the litigation so far is directed at USDA's initial closing of the border), this article suggests that this mechanism is useful in the future to challenge unfair judicial outcomes instigated by domestic special interests. Chapter 11 plaintiffs have not been very successful in the past. However, if there ever was a case of that could succeed, the mad-cow disease saga fits the bill.

Shelley v. Kraemer, 334 U.S. 1 (1948) [Shelley]. In this case the U.S. Supreme Court found that the judicial enforcement of contracts were "state action" as defined under the Constitution. Further if such contracts discriminated on racial grounds, their enforcement would be a violation of the Equal Protection clause of the Fourteenth Amendment. In entering into the NAFTA, Congress debated whether the U.S. would be liable for the actions of individual states: H.R. Doc. 103-159, 103rd Cong., 1st Sess., v. 2 at 5 (1993). On this point, the federal government concluded that they would indeed be liable for noncompliant state action: see "Letter from Michael Kantor, to Hon. Henry A. Waxman, Chairman, Subcommittee on Health and the Environment” 1993 U.S.C.C.A.N. 2858 at 2862. Though the same cannot be definitively said about the actions of state judiciaries, as the more common interpretation of state action is legislative or executive: see Krauss, ibid. at 90. The Shelley case, however, seems to suggest that judicial action should be counted as state action, especially when the judiciary is that of federal government, the very body that signed the NAFTA. 
This page is blank - do not strip it in 